\title{
Atendimento educacional especializado (AEE) em uma sala de recursos: Aquisição da linguagem oral da criança no espectro autista
}

\section{Asistencia educativa especializada (AEE) en un aula de recursos: Adquisición del lenguaje oral en niños del espectro autista}

DOI: $10.46814 / 1 a j d v 4 n 1-003$

Recebimento dos originais: 01/12/2021

Aceitação para publicação: 18/01/2022

\author{
Sandréia Pantoja Lobato \\ Mestre em Psicologia \\ Universidade Federal do Amazonas -UFAM \\ E-mail: sandy.psilobato@gmail.com \\ Kamile Oliveira Gadelha \\ Licenciada em Pedagogia \\ Universidade Federal do Amazonas -UFAM \\ E-mail: kamilegadelhalf@gmail.com
}

\section{RESUMO}

O presente trabalho tem por propósito versar sobre a Aquisição da Linguagem Oral da Criança com Transtorno do Espectro Autista (TEA), na perspectiva da sala de recursos multifuncional do Atendimento Educacional Especializado (AEE) numa Escola Municipal de Parintins a qual buscamos investigar a complexidade dos fenômenos educacionais que tramitam no processo de aquisição da linguagem oral da criança com TEA e as práticas pedagógicas usadas pelo professor no referido ambiente, haja vista que o desenvolvimento da linguagem, em alguns casos de TEA, este ocorre de maneira atípica, necessitando de uma estimulação específica. Assim, em parceria com o Programa Institucional de Bolsas de Iniciação Científica- PIBIC, do Instituto de Ciências Sociais, Educação e Zootecnia - ICSEZ/UFAM realizamos pesquisas bibliográficas, de campo e estudos de caso para um maior entendimento sobre a temática.

Palavras chave: Atendimento Educacional Especializado, TEA, Aquisição da Linguagem.

\section{RESUMEN}

Este trabajo tiene como objetivo abordar la Adquisición del Lenguaje Oral de los Niños con Trastorno del Espectro Autista (TEA), desde la perspectiva de la sala de recursos multifuncionales del Servicio de Educación Especializada (AEE) en una Escuela Municipal de Parintins en la que pretendemos investigar la complejidad de los fenómenos educativos que atraviesan el proceso de adquisición del lenguaje oral de los niños con TEA y las prácticas pedagógicas utilizadas por el profesor en ese entorno, dado que el desarrollo del lenguaje en algunos casos de TEA, este se produce de forma atípica, requiriendo una estimulación específica. Así, en colaboración con el Programa Institucional de Becas de Iniciación Científica - PIBIC, el Instituto de Ciencias Sociales, Educación y Ganadería - ICSEZ / UFAM realizamos búsquedas bibliográficas, estudios de campo y de caso para una mayor comprensión del tema.

Palabras clave: Asistencia Educativa Especializada, TEA, Adquisición del Lenguaje. 


\section{INTRODUÇÃO}

O presente trabalho versa sobre os interesses e inquietações que nos motivaram a dialogar sobre a temática em questão, tendo como objetivos norteadores: identificar, categorizar e avaliar as práticas pedagógicas desenvolvidas na sala de recursos multifuncional do AEE para a aquisição da linguagem oral da criança com TEA.

Tal pesquisa nos conduziu num afundamento nas teorias sócio-interacionista de Lev Semenivich Vygotsky, de compreendermos que a linguagem, pensamento e comportamento estão intrinsecamente ligados, e que a linguagem tem forte influência sobre os demais.

Nos estudos de Vygotsky ele toma a linguagem como instrumentos que mediará as formas como o indivíduo se relacionará com o mundo, ou seja, a partir do momento que eu me relaciono com o mundo, terei o entendimento acerca dele e consequentemente, poderei participar dele, intervir sobre dele, transformar ele.

Assim, percebemos que, em se tratando de crianças com TEA, ensiná-lo a dizer uma determinada palavra não significa necessariamente que ela está adquirindo a linguagem de fato. Isso é só uma parte do processo.

Para que essa palavra, uma vez dita, se torne linguagem mediadora, é preciso que o falante tenha ciência do "porquê", do "para quê" e "para quem" ela será dita. Constatamos, ao longo de nossa pesquisa, que quando se fala em Autismo entramos num campo ainda muito complexo e mistérios, pois suas causas ainda não são bem delimitadas assim como os motivos das diversas manifestações e intensidades que o transtorno se apresenta.

Porém, em todos os exemplos de casos estudados ao longo do presente trabalho, a aquisição da linguagem oral e/ou gestual configura-se como um elemento de destaque para o desenvolvimento da autonomia e a inclusão do indivíduo tanto no contexto escolar, extraescolar. Partindo disso que buscamos em Vygotsky nossa fundamentação teórica, pois segundo o autor a aquisição da linguagem vem como um divisor de águas para o homem, pois ao mesmo tempo em que ele faz uso dela para a comunicação com o meio social, ele a internaliza como elemento organizador do pensamento assim influenciando o planejamento das suas ações.

Partindo desses princípios, alicerçamos nossas observações dos colaboradores envolvidos na pesquisa: a professora do AEE e o aluno com TEA, oportunizando construir as análises, discussões de dados e conclusões sobre a temática em questão.

\section{METODOLOGIA}

Com o intuito de investigar a complexidade dos fenômenos educacionais que tramitam no processo de aquisição da linguagem oral da criança com TEA e as práticas usadas pelo professor na 
sala de recursos do AEE, elegemos como método de investigação a abordagem qualitativa, pois "procura reduzir a distância entre a teoria e os dados, entre o contexto e a ação, usando a lógica da analise fenomenológica, isto é, da compreensão dos fenômenos pela sua descrição e interpretação" (TEIXEIRA, 2009, p. 137).

Alicerçamos a pesquisa no enfoque fenomenológico-hermenêutico haja vista que buscamos evidenciar a relação entre o fenômeno e a existência, ou seja, a relação entre fenômeno vivido e aquele que vivencia a essência assim, a complementar, usamos como tipo de pesquisa o estudo de caso que "privilegia um caso em particular, uma unidade significativa, [...] indicando as possibilidades para sua modificação". (GONSALVES, 2007, p. 69).

O local eleito para a pesquisa foi uma sala de recursos multifuncional do Atendimento Educacional Especializado (AEE) localizada numa Escola Municipal na zona periférica no município de Parintins, tendo como colaboradores da pesquisa o professor da sala de AEE e o aluno com TEA, ambos eleitos por se tratar de peças fundamentais no entendimento do processo de aquisição da linguagem.

Utilizamos como instrumento de coleta de dados a observação direta no ambiente escolar, que nos beneficiou com a aproximação da realidade local pelo fato de que "a maior vantagem do uso da observação em pesquisa está relacionada à possibilidade de se obter informações na ocorrência espontânea dos fatos.” (BARROS, 1990), aplicamos também uma entrevista semiestruturada, pois de acordo com Barros (1990), o pesquisador, através de uma conversa amigável com o entrevistado, busca levantar dados que possam ser utilizados em análises quantitativas e qualitativas, selecionando os aspectos mais relevantes de um problema de pesquisa. Assim dividimos nosso trabalho de pesquisa em etapas:

Primeira etapa: levantamento da literatura pertinente a temática em questão, seguida de estudos, análises e fichamentos. Segunda etapa: Estudo de Caso, nesta fase foi coletado os dados por meio da observação direta do ambiente da sala de recursos do AEE. Permanecemos de agosto de 2014 à dezembro do mesmo ano no ambiente escolar acompanhando em loco o desenvolver do atendimento do aluno com TEA bem como as práticas desenvolvidas no processo de aquisição da linguagem oral. Terceira etapa: sistematização, análise e interpretação dos resultados coletados na pesquisa de campo para elaboração do relatório final.

\section{FUNDAMENTAÇÃO TEÓRICA}

\subsection{AUTISMO E SUAS IMPLICAÇÕES}

Os levantamentos bibliográficos que serviram de alicerce na produção do presente relatório foram de suma importância e ponto de partida para a elaboração das questões que nortearam a 
problemática do nosso tema. Assim, trazemos à discussão primeiramente os "porquês" que nos inquietaram sobre aquisição da linguagem em crianças com Transtorno do Espectro Autista e na busca dos primeiros estudos sobre autismo trazemos ao diálogo Leo Kanner, psiquiatra austríaco erradicado nos Estados Unidos que iniciou seus primeiros estudos e publicações sobre "Autismo" por volta de 1943.

Kanner desenvolveu uma pesquisa que relatava 11 casos de crianças cujos comportamentos se diferenciavam de tudo já catalogado nas literaturas relacionadas às síndromes psicológicas até então registradas na época, "o aspecto mais marcante nos estudos iniciais de Kanner descrevia uma anormalidade inata no comportamento social, 'o isolamento ou afastamento social', que denominou retraimento autístico, notável desde os primeiros períodos do desenvolvimento" (RODRIGUES, 2010 p. 17-18).

Ele as descrevia como crianças socialmente isoladas e inflexíveis à quebra ou mudanças de rotinas; observou nelas também uma peculiar repulsa ao contato físico com outras pessoas como também aversão ao contato visual, não demonstravam interesses em dialogar com os demais agindo como se fossem pessoas surdas e em alguns casos nem chegavam a desenvolver a oralidade tão pouco tentar estabelecer comunicação não verbal.

Pelo fato do autismo se manifestar e afetar diferentes aspectos do desenvolvimento global da criança acometida pelo transtorno, a tentativa de agrupamento de tais características autísticas descritas acima não foram consistentes o bastante para explicar as infinitas combinações de sintomas que faziam cada caso de autismo ser singular, logo "[...] no DSM-V, as subdivisões deixaram de existir e todos ficaram sob o mesmo guarda-chuva do Transtorno do Espectro Autista, no qual o nível de comprometimento na fala, interação social e comportamentos repetitivos serão classificados como leve, moderado ou grave.” (GOERGEN, 2013 p.29).

A atual nomenclatura trouxe novos direcionamentos para se chegar ao diagnóstico de TEA, pois flexibilizou as categorias de agrupamentos comportamentais derrubando a arcaica ideia de que a pessoa para ser considerada autista não fala, não olha nos olhos e não gosta de contado físico; trazendo uma nova leitura comportamental que analisa qualitativamente os três comprometimentos centrais do transtorno: linguagem, sociabilidade e comportamentos restritos e repetitivos.

Imaginemos um autista que num primeiro diagnóstico foi classificado como severo por não falar e ter lapsos de comportamento agressivo e ao receber um tratamento clínico terapêutico pode vir a ser reclassificado com um grau leve ou moderado por evoluir e conseguir desenvolver suas habilidades comunicativas e comportamentais mesmo ainda sendo socialmente isolado.

Assim, com a nova concepção do Espectro Autista, o baixo comprometimento ou a inexistência de alguns prejuízos característico na pessoa autista, não exclui o possível diagnóstico tão pouco a 
aprisiona num determinado grau de autismo. Isso beneficiou não só o olhar evolutivo do transtorno e investimentos nos métodos terapeutas e intervenções no contexto educacional no tratamento do TEA, bem como facilitou a busca pelo fechamento do diagnóstico precoce, podendo assim iniciar as intervenções o quanto antes.

\subsection{AQUISIÇÃO DA LINGUAGEM}

A fala não é somente uma simples comunicação de pensamentos ou tão superficial ao ponto de somente servir para satisfazer de necessidade momentânea, Piaget (1999) afirma que a linguagem vai mais além quando diz que ela também assume papel instigador, uma vez estabelecida a comunicação, dentro do diálogo, a linguagem pode instigar ações, provocar e induzir atitudes, sentimentos e reflexões. Com o uso da linguagem podemos nos conectar ao outro ou outros, possibilitando traduzir nossos pensamentos em palavras ou gestos, assim como dissimulá-los, por meio dela construímos relações afetivas em diversas esferas sociais de nossa vida.

Ao mesmo tempo em que Piaget (1999) evidencia o caráter socializador inerente à linguagem mostra também que nem sempre essa finalidade linguística é atingida, para esta alteração atípica o autor denomina de linguagem egocêntrica. Segundo ele "esta linguagem é egocêntrica, em primeiro lugar porque a criança não fala a não ser de si mesma, e, em segundo porque não procura colocar-se no ponto de vista do interlocutor", logo, é uma fala não comunicativa "a criança repete pelo prazer de falar, sem nenhuma preocupação de dirigir-se a alguém, nem mesmo, às vezes, de pronunciar palavras que tenham sentido [...] ainda nada tem de socializador.” (PIAGET, 1999 p.09).

Associamos essa alteração linguística com os prejuízos concernentes à fala de pessoas com o TEA descrito nos estudos de Kanner e exemplificado por Rodrigues (2010) ao relatar um estudo de caso do Autista S, 11 anos de idade, quando era encaminhado ao banho, repetia continuamente a frase: "S vai tomar banho, vai, S vai tomar banho, vai..." após o banho, quando já estava fazendo outra tarefa não mais relacionada ao banho, o mesmo continuava a repetir a mesma frase. Percebemos que nesse caso a linguagem é usada de maneira descontextualizada, o Autista $S$ inicialmente fez relação da fala com ação num dado momento, porém, desprovido de teor comunicativo. Os enunciados eram repetidos por ele pelo simples prazer de falar, sem algum interesse comunicativo, como se estivesse cantarolando uma música.

Kanner justificou essa alteração comunicativa de ecolalia como "tendência a repetir emissões ouvidas, em vez de criá-las espontaneamente" (RIVIÉRE, 2004, p. 235) e em decorrência dessa repetição acaba havendo inversões pronominais. Por repetir tudo que escuta algumas pessoas com TEA apresentam “problemas relativos à utilização do pronome 'tu' em situações que pedem o uso do pronome 'eu' [...] isso denuncia uma desorganização parcial, às vezes total, do seu conhecimento como 
pessoa e como ser dotado de personalidade própria” (RODRIGUES, 2010, p 24).

Outra barreira comunicativa a qual acomete a criança com TEA está também ligada à dificuldade em estabelecer uma comunicação não verbal, bem como interpretar expressões faciais ou entonações de voz. O entendimento de um aceno com a mão indicando uma despedida, ou uma expressão facial de desagrado também são formas comunicativas que alguns autistas podem ter dificuldade de interpretar. (GOERGEN, 2013).

Corroborando com a afirmativa, Vygotsky (1998) diz que a linguagem não depende necessariamente de som, pois gestos e expressões também são elementos comunicativos, elementos esses que na pessoa com TEA há uma carência no seu entendimento e utilização dessas formas alternativas de linguagem. Nos casos de autismo em que manifesta tais prejuízos a comunicação se configura como um obstáculo a se transpassar para que a mesma se faça entender, se comunique com o meio social ao qual faz parte.

As alterações na linguagem não causam prejuízos somente nas competências comunicativas na pessoa com TEA, estas, por sua vez acabam se estendendo a outros aspectos da vida desse indivíduo como esclarece o autor:

\begin{abstract}
Alguns autistas não desenvolvem a fala por implicações na compreensão dos códigos linguísticos e demonstram retardo na compreensão da linguagem e, ainda notável desvio qualitativos no processo de expressão e concepção de ideias. Isso os impede de fazer uma leitura de mundo que possam compreender os significados das representações, criando obstáculos de comunicação na vida diária. (RODRIGUES, 2013, p. 23-24).
\end{abstract}

Visto que a linguagem é um instrumento mediador da relação do homem com o mundo, o déficit de tal competência gera não só um empecilho comunicativo no ato de dialogar com o outro como também dificulta o entendimento e a participação nas relações sociais. Derivado disso, que, geralmente, a pessoa com TEA é equivocadamente interpretada como aquela que gosta de ficar sozinha apática ao mundo, que aparenta não ter empatia, tão pouco criar vínculos de amizades com as pessoas ao seu convívio e achamos que ela "vive no mundo dela".

A aquisição da linguagem representa um marco significativo no desenvolvimento das funções psicológicas superiores do indivíduo, pois "habilita as crianças a providenciarem instrumentos auxiliares na solução de tarefas difíceis, a superarem as ações impulsivas, a planejar as soluções para um problema antes de sua execução e a controlarem seu próprio comportamento." (REGO 1995, p. $63)$.

Vygotsky não se limita somente a analisar a competência da linguagem em seu caráter comunicativo como também acrescenta que sua aquisição tem estreitas influências do pensar e agir uma vez que a forma de se relacionar com o mundo não é uma relação direta, o indivíduo utiliza-se 
desse instrumento mediador os quais são criados pela espécie humana resultantes da relação homem e meio social e cultural. Assim, o "desenvolvimento humano precisa ser entendido como constante relação que envolve o sujeito, a mediação e o mundo sócio/cultural.” (CRUZ, 2014 p, 56).

Sabido que a pessoa com TEA possui prejuízos nas áreas comunicativas, interação social e comportamentos restritos e repetitivos, consideramos então que a aquisição da linguagem trará ganhos significativos não só no âmbito das competências comunicativas, como também contribuirá para uma adequação comportamental, enfim, dará ao sujeito falante autonomia do seu agir e pensar dentro de um contexto social.

\subsection{ATENDIMENTO EDUCACIONAL ESPECIALIZADO DA CRIANÇA COM TEA}

Enquanto inclusa na rede de ensino regular, a criança com Transtorno do Espectro Autista necessita de subsídios que propicie sua plena participação nos processos de ensino e aprendizagem que atenda suas limitações. Cunha (2012) referindo-se à educação da criança autista numa perspectiva inclusiva afirma que "[...] independentemente do grau de severidade, deve ser vivenciada individualmente na sala de recursos e na sala de ensino comum, favorecendo a sociabilidade, porque incluir é aprender junto [...]” (p.32-33).

Uma vez que se faz necessário o convívio da criança com comportamentos autísticos (CUNHA, 2012) no ambiente da sala comum enquanto espaço de aprendizagem e socializador, ela também precisa receber uma educação individualizada que a favorecerá estabelecer relações recíprocas com o referido espaço, pois o processo de socialização da criança por apresentar autismo não se dá de forma espontânea como em crianças não autistas, uma vez que o envolvimento social com os demais depende do diálogo, seja ele verbal ou gestual, depende da habilidade de entender o ponto de vista do outro, da interação com o ambiente e com os indivíduos que o compõem, compreender as regras de convivência sociais e culturais de cada ambiente.

Ao mesmo tempo em que a criança por apresentar TEA tem o Direito Constitucional de acesso ao ensino regular em caráter de igualdade às crianças ditas normais como citado como um dos princípios a "igualdade de condições de acesso e permanência na escola” (art. 206, inc. I), ela também possui o direito de receber Atendimento Educacional Especializado específico às suas necessidades educacionais decorrentes do transtorno que a comete expressos na LDB (Lei $n^{\circ}$. 9394/96) nos artigos 58,59 e 60.

Portanto, (Decreto $\mathrm{n}^{\circ}$ 6.253, art. $1 \S 11^{\circ}$ ) “Considera-se atendimento educacional especializado o conjunto de atividades, recursos de acessibilidade e pedagógicos organizados institucionalmente, prestado de forma complementar ou suplementar à formação dos alunos no ensino regular." Logo a sala de AEE configura-se como um espaço em que se oferecem estratégias que ajude o aluno em suas 
necessidades educacionais específicas de sua deficiência, de modo que ele tenha acesso ao currículo escolar em caráter de igualdade aos demais alunos da sala regular de ensino.

Assim, é legítima e imprescindível a oferta de estratégia e recursos pedagógicos específicos para que a criança com TEA possa transpassar suas atuais limitações a fim de eliminar as barreiras que dificultam o seu pleno desenvolvimento dentro e fora contexto escolar, pois "a criança com necessidades educacionais especiais por apresentar autismo, [...] precisa que lhe seja ensinado quase tudo que uma criança normal aprende espontaneamente por meio da observação e da experiência.” (DO MONTE; DOS SANTOS, 2004 p. 15).

Tendo em vista as especificidades comportamentais concernentes ao transtorno do espectro autista, a sala de recursos torna-se um espaço no qual o aluno receberá uma educação individualizada cuja ênfase será tanto a mudança de comportamentos impulsivos e indesejáveis bem como o aprendizado de outros (CUNHA, 2012).

A sala de recursos multifuncionais onde se realiza o Atendimento Educacional Especializado assume a função de subsidiar tais estratégias e recursos pedagógicos objetivando promover a acessibilidade e autonomia da criança com necessidades educacionais especiais tanto em sala regular como em todo ambiente escolar assim "o professor do AEE poderá contribuir orientando os profissionais da escola na elaboração de estratégias no cotidiano escolar, na elaboração de recursos e na organização da rotina, de acordo com as peculiaridades e cada aluno e cada escola." (BELIZÁRIO FILHO e CUNHA, 2010 p. 39).

O atendimento educacional especializado, não somente oportunizará uma inserção da criança com TEA no ambiente da sala de recursos, como também estabelecerá um diálogo contínuo com a sala regular objetivando tanto a socialização nesse espaço heterogêneo bem como em todo ambiente escolar.

\subsection{PRÁTICAS PEDAGÓGICAS}

Na perspectiva do atendimento educacional especializado, espera-se que o professor da sala de recursos multifuncionais tenha uma consciência inclusiva a qual, primeiramente este extingue rótulos (CUNHA, 2012) comumente associados às arcaicas ideias de pessoa deficiente; e em segundo, que este desenvolva ações de qualidade oportunizando a acessibilidade dessa criança com TEA frente às barreiras a ser transpassado, assim ele deve ser ciente do seu papel e compreender que "[...] é por meio do aprendizado que a criança pode adquirir consciência do mundo e dela própria, e que esse aprendizado passa pelo desenvolvimento da comunicação [...]”. (DO MONTE; DOS SANTOS, 2004 p. 16).

Como bem citado, a aquisição da linguagem para a criança autista, não se resume a uma 
conquista que trará benefícios na esfera comunicativa como também se configurará num instrumento mediador na relação dela com o mundo bem como sua interação com o meio social, resgatando-a do isolamento autístico. Vygotsky destaca em seus estudos que esta aquisição é um marco de grande importância no desenvolvimento da criança, pois:

“[...] a linguagem habilita as crianças a providenciarem instrumentos auxiliares na solução de tarefas difíceis, a superar ações impulsivas, a planejarem a solução de um problema antes de sua execução e a controlarem seu próprio comportamento. Signos e palavras constituem para as crianças, primeiro e acima de tudo, um meio de contato social com outras pessoas [...] sendo assim, a linguagem tanto expressa o pensamento da criança como age como organizadora do pensamento." (p. 63,64).

Assim, uma vez a linguagem adquirida, esta passa por um processo de internalização, ou seja, a criança passa a utilizar esse instrumento mediador para organizar e antecipar mentalmente suas ações refletindo sobre quais possíveis atitudes tomar para determinadas ocasiões do cotidiano. A internalização da linguagem nada mais é que falar mentalmente invocando as experiências adquiridas, organizando o pensamento tanto para as tomadas de atitudes como para entender o mundo que o circunda dando mais autonomia para a criança participar das relações sociais.

A inserção do aluno com TEA no contexto escolar passa por um processo de adaptação às normas e regras de convivência do local de ensino, nesse sentido, Do Monte e Dos Santos (2004) colaboram com a afirmativa de que essa aprendizagem seja alicerçada por um ensino estruturado que "pode introduzir um novo repertório de competências ao mesmo tempo em que pode aumentar a autonomia com relação às atividades da vida diária, como, por exemplo, comer e vestir-se” (p. 17).

Em se tratando de métodos de sistemas de comunicação e/ou modificação comportamental na perspectiva de aumentar a autonomia da pessoa com TEA é comum ouvirmos falar em TEACCH, ABA, PECS. Tais siglas correspondem a um tipo de método a ser aplicado à pessoa com espectro autista com a finalidade de torná-la independente, de modificar comportamentos inadequados bem como introduzindo novas habilidades, de desenvolver a linguagem oral ou também usá-los como sistema de comunicação alternativa para os casos de afasia (ausência da fala).

$\mathrm{O}$ método TEACCH (Treatment and Education of Autistic and Related Communication Handicapped Children) que em português significa Tratamento e Educação para Autistas e Crianças com Deficiência Relacionada à Comunicação teve como base de sua formulação o conceito de Autismo na perspectiva dos distúrbios relacionados à comunicação, à intervenção social, e à cognição. (RODRIGUES, 2010)

De fundamentação Behaviorista o método TEACCH procura intervir de forma a modificar os aspectos comportamentais inadequados da criança com espectro autista: 
[...] os distúrbios de comportamentos do autista podem ser modificados à proporção que ele consegue entender o êxito de suas expressões verbal ou gestual no ambiente, bem como o que se espera dele em certas circunstâncias [...] o funcionamento comportamental adaptativo do autista é consideravelmente melhor em condições estruturadas. (RODRIGUES, 2010 p. 80).

O método ABA (Análise Aplicada do Comportamento), assim como o TEACCH, provindos da Psicologia Behaviorista propõem a estimulação determinados comportamentos já preestabelecidos, ou seja, delimita qual a habilidade que se quer desenvolver, entretanto, o método ABA parte de uma análise de quais habilidades o autista já possui para que então se possam introduzir novas. "Cada habilidade ensinada por etapas estabelece uma organização de atendimento individual. Os trabalhos de estimulação ao aprendizado de novas aptidões são apresentados ao aluno com auxílio de uma indicação ou instrução". (RODRIGUES, 2010 p. 84).

Ambos os métodos sofrem críticas no que diz respeito à forma de ensino, pois “[...] reside na prática de uma concepção de educação mecanicista, adestradora, mais inclinada a robotizar do que a promover as genuínas potencialidades humanas.” (RODRIGUES, 2010 p. 85-86).

São classificados como métodos que não propiciam a estimulação da espontaneidade, haja vista que a habilidade a qual se pretende desenvolver com tais métodos não parte do sujeito ao qual adquire a habilidade, mas sim de quem a vai aplicando os mecanismos que serão transmitidos as habilidades.

O sistema PECS (Picture Exchange Communications System) busca a espontaneidade da comunicação através de trocas de figuras a qual objetiva "ajudar a crianças e adultos portadores da síndrome autística [...] a adquirir habilidades de comunicação.” (RODRIGUES, 2010 p. 86). Tem como pressuposto metodológico a descoberta de uma motivação para a criança autista como ponto de partida para se estimular a comunicação.

O desejo e a necessidade de como e o que comunicar vem da criança, a possibilitando uma gama de mecanismos visuais a qual poderá lançar mão para expressar seus desejos e estabelecer relações comunicativas com o meio social.

Assim os mecanismos de comunicação alternativa vêm como um instrumento facilitador para o desenvolvimento da pessoa com TEA tanto em suas competências comunicativas, como no agir enquanto ser social, na autônima das atividades do cotidiano, bem como refletirá em seu processo de aprendizagem.

\section{RESULTADOS E DISCUSSÃO}

\subsection{CARACTERIZAÇÃO DO AMBIENTE DA SALA DE AEE}

Na primeira etapa de execução do presente projeto de pesquisa, ingressamos no ambiente da sala de recurso de uma Escola Municipal do Ensino Fundamental localizada em zona periférica de 
Parintins-AM.

Trata-se de uma sala ampla, climatizada, onde há diversos materiais psicopedagógico, como: jogos de quebra-cabeça, memória, material dourado, alfabetos móveis, jogos numéricos, dominós, instrumentos musicais, livros, DVD’s de jogos, histórias e musicais, televisão, computador com tecnologia assistiva, impressora multifuncional; para as atividades psicomotoras a sala conta também com bolas de futebol e pilates, corda para pular, bambolês, petecas, colchonetes, cones e barras de obstáculos, nos quais as atividades com esses materiais eram desenvolvidas com o atendido na quadra poliesportiva da escola.

Dentre os atendimentos educacionais especializados realizados, assistiam três crianças com o diagnóstico de Transtorno do Espectro Autista. No entanto, somente uma estava frequentando os atendimentos. Os responsáveis dos outros dois alunos não frequentadores, segundo a professora, tinham consciência da importância dos atendimentos, porém, havia conflitos de horário ficando inviável levá-los.

Um dos alunos não frequentadores apresentava problemas para dormir e resistia a acordar cedo. A mãe do outro aluno - que também não frequentava os atendimentos do AEE - justificou a ausência do filho em não ter um adulto responsável que o levasse aos atendimentos, pois ele ficava em casa sob a supervisão da outra filha, irmã mais velha pré-adolescente, enquanto os pais trabalhavam e como a família residia longe da escola, eles não autorizavam que a irmã o levasse para a escola por julgarem ser perigoso.

Assim nossa prática de campo foi voltada à observação das práticas educacionais desenvolvidas para a aquisição da linguagem oral no atendimento de uma criança com TEA, dos quais eram feitos duas vezes por semana na sala de recursos multifuncional, com duração de duas horas tendo como atendente uma professora especialista em psicopedagogia.

\subsection{A OBSERVAÇÃO DOS ATENDIMENTOS NO AEE DO ALUNO COM TEA}

Sobre o atendido, trata-se de uma criança com afasia, ou seja, fala até então inexistente assim como apresenta comunicação não verbal atípica. $\mathrm{O}$ aluno tentava comunicar suas vontades e interesses nos levando ao objeto ou local que desejava, nos usando como ferramenta para atender suas vontades, exemplo disso ocorria quando ele queria assistir algum vídeo ou jogar no computador. Pegava-nos pela mão e encaminhava-nos ao computador encostando nossa mão na tela; quando perguntado se ele queria que ligássemos ele reagia com gritos e repetia o movimento de encostar nossa mão na tela. Nas suas ações em tentativa de respostas às perguntas como: você quer que eu ligue o computador? Você quer assistir vídeo? Você quer jogar o joguinho da pescaria? A reação do aluno continuava a mesma de levar a mão da professora à tela. 
Não foi identificada resposta negativa ou positiva para as perguntas feitas pela professora, porém houve situações em que a professora respondeu negativamente à tentativa do aluno para ligar o computador e o mesmo entendeu que não seria feita a sua vontade, ou seja, ele tinha o entendimento e obedecia aos comandos "NÃO" e "SIM". Tal comportamento também foi observado em outros contextos como quando estava com vontade de comer ou com sede e pegava sua mochila como indicativo para satisfazer suas necessidades alimentares.

Percebemos que pelo fato dele não conseguir especificar suas preferências de atividades - o aluno queria usar o computador, mas não informava qual atividade desejava realizar nele, mesmo sendo lhe dado opções para escolher - o aluno nos transmitiu a impressão de que essas limitações comunicativas lhe causavam um sentimento de angustia que, consequentemente vinham acompanhadas de gritos e movimentos de balançar as mãos. Ao passo que a professora dizia que não estava na hora de usar o computador, ele, mesmo sendo contrariado, obedecia à negativa da professora.

Não ficava claro qual era a vontade do aluno ao nos encaminhar para um determinado local ou objeto, a professora descobria por eliminação e também por já saber quais eram as preferências do aluno. Essas táticas foram sendo adquiridas ao longo dos dois anos em que veio trabalhando no atendimento do mesmo. O fato de não ficar claro o desejo dele em fazer ou não determinada tarefa geravam constantes crises de irritabilidade que alterava todo o comportamento do aluno interrompendo o atendimento para iniciar o processo de acalmá-lo.

Dentre as alterações comportamentais característica do espectro autista, observamos no aluno constantes emissões de gritos e sons de roncos em simultâneo com movimentos vibratórios de lábios de língua os quais o emite tanto em situações prazerosas e eufóricas assim como em momentos de desagrado e raiva.

Notamos também relutância em executar atividades motoras que exigem um maior esforço da coordenação motora fina, no entanto ele as fazia, mesmo que em sua maioria não esboçasse interesse no momento da execução, assim como pouco fixava o olhar nelas. Houve situações que chegou a chorar transmitindo sentimento de desagrado em ter que executá-las, porém mesmo não sendo do seu agrado ele entendia que aquelas atividades propostas pela professora teriam que ser finalizada e assim ele as fazia.

As atividades que exigiam mais concentração e habilidades de coordenação motora fina consistiam em pintura de moldes das letras do seu nome com tinta guaxe e pincel de pelos de espessura grossa, contar e classificar por cores, texturas e tamanhos dos objetos como: palito de picolé, recortes de T.N.T, tampas de garrafas, bolas de diversos tamanhos e consistências, formas geométricas, imagens de diversos elementos do seu cotidiano, blocos de encaixe e etc.

Nas atividades que exigiam um maior esforço da coordenação motora ampla, o atendido 
demonstrava satisfação em realizá-las, mostrava-se entendedor dos comandos de correr em determinadas direções, passar por debaixo de um obstáculo, andar em zig-zag entre cones, movimentar membros inferiores e superiores, girar corda e bambolês, elevar o tronco do corpo quando deitado, dançar e etc. muitos desses exercícios eram executados apenas com o comando oral da professora, outros necessitavam demonstração e auxílio para com o aluno em sua execução.

No período observacional presenciamos as dificuldades da professora em aplicar as atividades planejadas assim como aumentar o seu grau de complexidade. As frequentes estereotipias comprometiam a concentração do atendido no momento de execução das atividades, bem como sua relutância na inserção de um novo repertório de atividades. Isso ocorria pelo fato do aluno resistir às mudanças e/ou quebra de rotinas, característico do transtorno.

Goergen (2013) explica essa inflexibilidade à quebra de rotina dizendo que é uma tentativa da pessoa autista em manter-se numa zona de conforto tendo contato e realizando tarefas que já é de seu conhecimento, no entanto a criança também deixa de experimentar mudanças que poderiam gerar novos aprendizados ampliando seu repertório de experiências.

As estereotipias eram constantes, tais como os movimentos de balançar das mãos, sacudir a cabeça, girar o corpo em seu próprio eixo, bater a palma da mão no chão e correr ao redor da mesa eram constantes e todos associados aos sons de gritos e roncos e movimentos vibratórios com lábios e língua entre os dentes.

Nas competências comunicativas, percebemos que ele compreende gestos e comandos orais da professora, porém, no período observacional não foi visto alguma tentativa do aluno em reproduzi-los para se expressar, reagia como se fosse somente um receptor de informações e comandos ditos pela professora. Ele os assimilava e executava quando é do seu agrado, quando não, a reação de recusa desencadeava as desestabilidades comportamentais de movimentos estereotipados.

Em decorrência das constantes agitações do aluno associadas às estereotipias que comprometia o andamento do atendimento, a professora concentrava seus esforços e boa parte do tempo em acalmálo com músicas, massagem, alongamentos para tentar amenizar tais comportamentos, pois considerava a adequação comportamental era uma necessidade urgente. Empenhava-se em ensiná-lo a lhe ouvir e atender aos seus comandos para que o aluno pudesse concluir as atividades programadas no atendimento do dia. Geralmente obtinha êxito e conseguia dar continuidade às atividades programadas, mas houve casos que não foi possível concluir o cronograma de atividades, pois as técnicas não funcionaram.

Acreditamos que, baseados nas teorias de Vygotsky, tais reações sejam resultantes da dificuldade que o atendido apresentava ter em se colocar no diálogo, constatamos que as crises de alterações comportamentais refletiam a frustação que o atendido tinha em não conseguir expor, de 
forma inteligível para a professora, suas vontades no processo de desenvolvimento do atendimento. Acreditamos que há uma vontade por parte do aluno de não somente ser um mero receptor, mas também de intervir no ambiente de modo a transmitir seus pensamentos e desejos.

Consideramos ser latente a estimulação para a aquisição da linguagem oral e/ou gestual, uma vez que trará ao aluno maior domínio sobre as ações impulsivas, como também um grande repertório signos linguístico que o ajudará a intervir sobre o ambiente da sala de recurso do AEE, assim melhorar sua relação comunicativa com a professora do AEE. Relação essa de fundamental importância no processo de ensino e aprendizagem, pois esse processo deve ser construído partir dos interesses e necessidades específicas do aluno.

\subsection{ENTREVISTA COM A PROFESSORA DO AEE}

Cumprindo o objetivo da pesquisa para um maior aprofundamento da temática do projeto, realizamos a presente entrevista semiestruturada como forma de nos inteirarmos mais, sob a perspectiva da professora da sala de recurso do AEE, a respeito do atendimento realizado ao longo do ano de 2014.

Elaboramos algumas questões para nortear um diálogo com a professora, mas nosso objetivo maior era ouvir qual sua análise pessoal sobre o trabalho desenvolvido no atendimento do aluno autista observado. Assim iniciamos a entrevista perguntando qual foi a maior dificuldade enfrentada no atendimento do aluno com TEA?

A professora relatou que sua maior dificuldade foi a barreira comunicativa, pois segundo ela "como se tratava de um aluno com um autismo mais severo, ele não fala, ele tem reações diferentes, não se comunica com palavras e isso para mim foi muito difícil pois não sabia identificar seus comportamentos, saber o que ele estava sentindo, se ele estava triste ou com raiva, se ele precisava usar o banheiro, se estava com fome e ao longo do tempo que fui aprendendo, resultado da convivência com o aluno."

A professora já estava em seu segundo ano, trabalhando no atendimento com o referido aluno. No primeiro ano, em 2013, exercia a função de Auxiliar à Docência, ou seja, auxiliava a professora titular nos atendimentos dos alunos assistidos naquele local e em 2014, ocupou a posição de professora titular dos atendimentos desenvolvidos na referida sala de AEE. Logo, o considerável período em que esteve envolvida no processo de atendimento do aluno realmente colaborou na sua leitura sobre as adversidades relacionadas às alterações comportamentais do aluno, como também ajudou a intervir com mais rapidez e até mesmo diminuir a contingência delas.

Acrescentou também que, inicialmente, o pouco de conhecimento sobre o Transtorno do Espectro Autista também foi um grande obstáculo a se transpassar. Que diante daquele desafio buscou 
embasamentos teóricos tanto para entendê-lo como também fazer com que ele evoluísse em seu aprendizado. Assim direcionou o atendimento do aluno ao que classificou como mais latente e primou intervir sobre as esferas comunicativas e comportamentais, uma vez que as considerava em maior grau de prejuízo no aluno.

Em sua fala, explicitou sua inicial insegurança em como proceder ao atendimento do referido aluno, pois mesmo tendo uma especialização em Psicopedagogia, alegou que como se tratava de uma "síndrome nova" admitiu que a temática sobre Autismo e as possíveis práticas pedagógicas voltadas para especificidade da pessoa com TEA, tinha sido contemplada de forma superficial ao longo de sua formação, como também expos sua dificuldade em achar literaturas que abordassem sobre os tipos de atendimentos específicos para pessoas com TEA e suas intervenções para o desenvolvimento da linguagem.

Perguntamos em seguida qual foi o avanço mais significativo percebido ao longo do atendimento do aluno?

Em resposta ela pontuou que: "ele passou a ter mais autonomia, principalmente na questão de ir ao banheiro, na hora do lanche em obedecer aos comandos de ficar na fila, ir à biblioteca, ir para a sala de vídeo, se portar melhor com os colegas assim como também na parte didática, pois em algumas atividades observamos que ao longo do tempo ele começou a fazer com menos dificuldades do que fazia antes, como por exemplo: pegar num lápis, num pincel, pintar com a tinta [...] observei também uma evolução na questão do movimento, nas práticas de psicomotricidade que ajudaram muito o aluno".

Portanto, a professora considerava que o atendido, comparado ao início do ano, demonstrou mais confiança tanto nas atividades motoras, como também nas atividades da rotina da vida escolar. "Passei a observar que ele brinca mais, que está mais calmo, que sorri mais, se mostra mais satisfeito. Prova disso que no último atendimento, ele mesmo sentou à mesa, pegou o lápis e o material e ficou fazendo. Para nós isso é um avanço imenso."

$\mathrm{Na}$ avaliação realizada pela professora, percebemos que a mesma enfatizou uma melhora significativa no comportamento do aluno, da autonomia do aluno em realizar tarefas do cotidiano escolar. Relatou que o aluno estava mais participativo, e "melhorou suas constantes estereotipias, que escutava mais, se acalmava mais rápido". Percebemos em seu discurso a ênfase que atribuía à adequação comportamental em detrimento à estimulação da linguagem, pois as alterações do comportamento do aluno desestruturavam toda a dinâmica planejada para o atendimento. Buscava em sua prática sempre mantê-lo calmo, pois julgava ser a melhor forma de fazê-lo entendê-la e assim realizar as atividades propostas para o atendimento.

Analisando sua fala, reafirmamos nossas impressões de que a professora desenvolvia os 
atendimentos ao aluno de modo a habilitá-lo para cumprir tanto as regras de convivência do ambiente escolar como executar seus comando e atividades, ou seja, observamos em sua prática uma aproximação dos métodos behavioristas que pouco estimula a espontaneidade, característica genuinamente humana; nas palavras de Rodrigues (2010), uma robotização.

Prosseguimos a entrevista perguntando, dentre tantas características manifestadas no aluno decorrente do TEA, o que mais lhe inquietou ao iniciar o atendimento do aluno que serviu de ponto de partida para sua intervenção psicopedagógica?

Em seu discurso, percebemos uma grande preocupação em adequar o comportamento do atendido no sentido de diminuir a contingência das estereotipias e acalmá-lo mais, pois o considerava bastante agitado e atribuía que isso decorria de uma carência de atendimento clínico.

Tinha ciência que esse aspecto clínico não competia à sua área, mas conhecia outros casos de alunos com TEA que faziam uso de medicamentos que ajudavam a amenizar tais comportamentos atípicos e controlavam as estereotipias e consequentemente melhoravam a concentração. Ciente que cada caso de autismo era singular e que as questões de intervenção medicamentosa eram assuntos que cabiam à família e aos médicos decidirem fazerem uso ou não, a professora acreditava que esse método podia ser uma alternativa para melhorar o comportamento e o desempenho do aluno e seu desenvolvimento, porém resguardava sua opinião, pois sabia que o posicionamento familiar era contrário às intervenções medicamentosas.

Segundo ela: "foi mais a parte do atendimento clínico, pois eu percebia que ele era muito agitado, que as estereotipas dele eram muitas e cada dia era uma diferente, [...] vejo que esse aspecto do atendimento clínico é uma necessidade, pois tinha dias que ele estava muito agitado que ele não parava um minuto e não conseguíamos realizar nenhuma atividade, pois ele não tinha concentração”.

Relatou também que "o que me inquietou muito nele era essa constante agitação dele, muitas estereotipias em quase todo corpo, sentia ele muito ansioso" e diante das circunstâncias buscou técnicas de relaxamento como massagem e músicas como forma de acalmá-lo e assim conseguir iniciar as atividades propostas.

A família do atendido foi crucial nesse processo, relatou que colhia informações com a mãe do aluno sobre as preferências musicais e técnicas que a família usava para acalmá-lo em casa e assim reproduzi-las na sala do AEE objetivando criar um ambiente acolhedor que proporcionasse segurança ao aluno.

Sabia que para o aluno a rotina era algo muito presente no contexto familiar e buscava reproduzir tais princípios em seu atendimento, pois muitas vezes a quebra dessa rotina causava mais crises de agitação. Tinha ciência de que nem sempre era possível manter a rotina, pois, às vezes algo saia da rotina no contexto familiar e refletia no comportamento do aluno durante o atendimento. 
Dentro do contexto do atendimento, entendemos o posicionando da professora quanto à tentativa de manter um ambiente de modo que o aluno se sentisse a vontade e assim proceder ao atendimento sem maiores complicações, mesmo porque ela intuía que caso contrário, a insegurança causava sofrimento ao aluno. No entanto, acreditamos que essa "zona de conforto" configura-se como uma via de mão dupla, pois ao mesmo tempo em que o mantinha calmo, também o aprisiona e estagna seu desenvolvimento, acrescentar novos elementos ao repertorio do atendimento é quebrar a rotina já estabelecida, ou seja, tentar novas estratégias saindo da atual "zona de conforto".

Ao finalizar as questões que usamos para nortear entrevista, perguntamos se ela gostaria de acrescentar algo a mais, e, no momento de desabafo falou: "Tentamos avançar com aquilo que temos e sabemos que precisa melhorar muito, também precisamos de muita ajuda principalmente da família. Precisamos também de apoio, porque um dia podemos precisar de orientações de um especialista como o fisioterapeuta, um fonoaudiólogo e nem sempre conseguimos, mas, mesmo assim, fazemos aquilo que conseguimos com o que aprendemos ao longo desses anos e com a prática”.

Reafirmando suas limitações no que diz respeito à formação, mas com a vontade de buscar sempre aprimorar sua prática docente, ela relata que: "acredito que o conhecimento nós temos bem pouco, nós precisamos de profissionais que nos ajude mais nessa questão de informação. Eu digo que eu aprendi mais aqui com os alunos e depois que eu fui buscar mais conhecimento científico, mais na prática mesmo e, pra mim, isso é o mais importante, pois se eu tiver muito conhecimento dessas partes das leis, dos teóricos e seus conceitos científicos e eu não conhecer a realidade daquele aluno eu não vou saber trabalhar com ele".

Esta entrevista foi realizada no dia 16/12/2014, os atendimentos do aluno com TEA já tinha se encerrado. A professora do AEE estava finalizando a parte burocrática de produção dos relatórios anuais dos atendimentos desenvolvidos no ambiente. Não tivemos acesso a estes documentos, no entanto disponibilizamos para escola nossos escritos sobre o observado no referido ambiente.

\section{CONSIDERAÇÕES FINAIS}

Fazendo uma retomada dos objetivos iniciais ao qual nos propusemos investigar que consistia em identificar, categorizar e avaliar as principais práticas pedagógicas desenvolvidas pela professora do AEE na sala de recurso multifuncional para aquisição da linguagem oral da criança com Transtorno do Espectro Autista, a pesquisa nos trouxe dados significativos e até mesmo controversos no que se refere ao nosso entendimento inicial sobre aquisição da linguagem na perspectiva da criança com TEA uma vez inclusa no AEE na sala de recursos multifuncional.

Falo em controversos, pois, quando nos referimos à aquisição da linguagem, pensávamos inicialmente em proporcionar ao atendido mecanismo que desenvolvesse a fala, que o ato de dialogar, 
e a interação social seria uma consequência disso. No entanto, ao aprofundarmos nossos estudos bibliográficos em paralelo às observações das práticas pedagógicas desenvolvidas na sala de AEE, nos deparamos com o processo mais complexo.

A presente pesquisa contribuiu significativamente para minha formação ampliando meu olhar sobre os processos de aquisição da linguagem oral e gestual, bem como o entendimento que a aquisição dessa habilidade não só instrumentalizará o indivíduo nas competências comunicativas como também influenciará na forma como o indivíduo se relaciona com o mundo e participa das relações sócias.

Nas observações em campo, entendemos que há por parte da professora a vontade de instrumentalizar o aluno para que o mesmo controle suas ações impulsivas, tendo em vista a diminuição das estereotipias, o aumento da concentração e a evolução no processo de ensino e aprendizagem. No entanto, de acordo com nosso posicionamento sócio interacionista "Vygotskyano"; identificamos dentre as práticas desenvolvidas pela professora, um posicionamento behaviorista, ou seja, primazia em moldar o comportamento do aluno aplicando atividades já pre-delimitadas, a escolha dos estímulos para a aquisição de novas habilidades parte do professor.

Acreditamos que tal prática seja somente parte do processo, pois também concordamos com a prática da professora observada que a adequação comportamental, o autocontrole das ações impulsivas é uma necessidade latente na criança com TEA. Assim, reafirmamos que esse processo parte inicialmente pela aquisição da linguagem oral e/ou gestual e esta por sua vez instrumentalizará o aluno a evoluir nos aspectos comportamentais e cognitivos. 


\section{REFERÊNCIAS}

BELIZÀRIO FILHO, José Ferreira; CUNHA, Patrícia. Educação Especial na Perspectiva da Inclusão Escolar: transtornos globais do desenvolvimento. Brasília: Ministério da Educação, Secretaria de Educação Especial; [Fortaleza]: Universidade Federal do Ceará, 2010.

CUNHA, Eugenio. Autismo e inclusão: psicopedagogia práticas educativas na escola e na família. $4^{\mathrm{a}}$ ed. RJ: : Wak Ed, 2012.

CRUZ, Talita. Autismo e inclusão: Experiências no Ensino Regular. Jundiaí, Paco Editorial: 2014.

DO MONTE, Rosineide Furtado; DOS SANTOS, Idê Borges. Saberes e práticas da inclusão: dificuldades acentuadas de aprendizagem: autismo / coordenação geral - reimpressão. Brasília: MEC, SEESP, 2004.

GOERGEN, M Sonia. Sobre o diagnóstico em transtorno do aspectro do autismo (TEA): Considerações introdutórias à temática. Campinas, SP: Papirus, 2013.

PIAGET, Jean. A linguagem e o pensamento da criança. 7 ed. SP: Martins Fontes, 1999. RIVIERA, Angel. $\mathrm{O}$ autismo e os transtornos globais do desenvolvimento. In: Desenvolvimento psicológico e educação. 2 ed. Porto Alegre: Artmed, 2004.

RODRIGUES, J. M. C. A criança autista: um estudo psicológico. RJ: Wak Editora, 2010.

REGO, Teresa Cristina. Vygotsky: uma perspectiva histórico-cultural da educação. Petrópolis, RJ : Vozes, 1995.

VYGOTSKY, Lev Semenovitch. Pensamento e linguagem. Tradução Jefferson Luiz Camargo; revisão técnica José Cipolla Neto. - $2^{\circ}$ ed. - São Paulo : Martins Fontes, 1998. 